\title{
Analysis on financing environment of small and medium sized
}

\section{enterprises}

\author{
ZHANG Rui \\ Jilin Business and Technology College P.R.China,130000 \\ 33388960@qq.com
}

Key words: Small and medium sized enterprises; Financing environment; Credit guarantee system

\begin{abstract}
Since the reform and opening up, the small and medium-sized enterprises have been developing, and the financial resources obtained are not commensurate with their position in the national economic and social development. SME financing has become one of the obstacles to the development of China's small and medium enterprises. Therefore, it is very important to analyze and solve the problem of financing of small and medium enterprises. In this paper, based on the above background, the financing environment of small and medium sized enterprises in China as the main line are analyzed, based on the accumulation of years of experience in solving the difficult problem of financing of small and medium-sized enterprises proposed effective strategies, break the environment for the small and medium-sized enterprises financing bottleneck, solving the financing problems, which to promote the rapid growth of small and medium enterprises to ensure sustained, rapid, coordinated and healthy development of the national economy has a very important practical significance.
\end{abstract}

\section{Introduction}

In the market economy environment, the financing of enterprises is generally through two channels to complete. First, the direct financing, through the issuance of shares and corporate bonds and other forms of financing; the second is indirect financing, mainly through bank loans and a variety of financial instruments to finance. At present, the small and medium-sized enterprise direct financing condition is not very ideal. Listed in the motherboard market, China's enterprises have more than 1000, most of which are state-owned enterprises, only a few mature products, good benefits , the market prospects of small and medium-sized enterprises can strive to direct listing financing, and in the bond market, small and medium-sized enterprise also is not a broker of alternative enterprises. So, for most small and medium-sized enterprises,indirect financing especially through the bank loan financing has become the most important means of obtaining funds. However, due to the problems existing in the small and medium-sized enterprises and the problems in the financial system of our country, the financing of small and medium-sized enterprises in the indirect financing market is not optimistic.

\section{Performance of small and medium enterprises financing difficulties}

External financing difficulties. Bank loan is an important channel of external financing, although between SMEs and financial institutions generally established stable cooperative relationship, but due to the relatively small scale of small and medium-sized enterprises, operating 
variables, risk, credit ability is low and so on a series of reasons, external financing constraints of small and medium sized enterprises is stronger than large enterprises .In addition a higher threshold of securities market, listed higher cost, market risk of small and medium-sized enterprises make itself through securities to lower external capital ratio , and is the introduction of the Gem for small and medium enterprises to create good financing environment, small and medium-sized enterprises should seize the opportunity to fight for the source of funds.

The high cost of small and medium enterprises. China's SME financial system survey report shows that the current financing costs of small and medium enterprises generally include loan interest, loan interest, including basic interest and floating part, the floating range of more than $20 \%$ in general. Vast majority of financial institutions in the loan has been reserved nominal interest rates and deduct part of the loan principal, medium and small businesses get loans only $80 \%$ of the principal amount.Taking one year loan as an example, the actual payment of the small and medium enterprises is about $9 \%$,approximately bank loan rate of more than $40 \%$. Thus, the high cost of financing for SMEs financing caused some impact.

Having adequate private capital, but the private financing needs to be standardized. China's social system and consumption habits lead to the existence of high savings rate. High savings of residents to make our country's private capital abundant, especially in economically developed areas, such as Guangdong, Zhejiang, private lending market is very active, to a considerable extent, instead of the bank's function. However, the private financing activities are basically in the underground or semi underground situation, the lack of law or the norms of the system, usury and other illegal activities are relatively common, so private financing needs to be standardized, so that the real development of the financing activities of the market.

\section{Analysis on financing difficult reason of small and medium-sized enterprise}

Corporation funding gap is increasing. Small and medium-sized enterprise financial system is not perfect, the internal control system is not perfect, information distortion, caused the bank and enterprise information asymmetry, making small and medium-sized enterprise financing encounter difficulty. In recent years, raw materials, labor, coal, electricity, oil and transport factor prices continued to rise, product market competition is becoming increasingly fierce, small and medium-sized enterprise sales increasing pressure, A large number of liquidity stranded in the production link ,funds for stock rose, a rapid increase in corporate demand for funds, commercial bank credit scale contraction. With the continuous implementation of the national tight monetary policy, the small and medium-sized enterprise credit supply was tight, affected by private lending confidence. Affected by the macroeconomic situation, some of the original efficiency of small and medium enterprises are facing difficulties and even close down, unable to repay the loan funds, the original is also a significant contraction of the more active private financing.

The sharp rise in corporation finance costs. Small and medium sized enterprises in our country are suffering from the high cost of funds. At present, the bank for small and medium-sized enterprises loan interest rates generally go up 30\%-40\%, $80 \%$ go up high. Also many banks also requires enterprise certificate of deposit pledge, the state-owned bank financing rates reached $11.65 \%$, joint-stock bank financing rates reached $15.4 \%$, if the loan is secured and security agencies average guarantee rate of 2-3 percentage points, the small and medium-sized enterprises to bear the financial cost of capital will be higher. The majority of local private financing monthly interest rates have been as high as 4 points to 6 points, the high cost of the use of funds for SMEs to have a greater impact on economic efficiency. 
Enterprise loan guarantee system is not perfect. Financing guarantee system can reduce the financing cost of small and medium sized enterprises. At present, Small and medium sized enterprises borrow funds from the private market price with high interest rates. And through the financing guarantee system, the financing cost of small and medium enterprises is the loan of bank interest plus a certain amount of fees, far less than the cost of raising funds from the private. For small and medium-sized enterprises, on the one hand, few fixed assets to mortgage, the loan is restricted; on the other hand, enterprises should handle a pen of the mortgaged property, are required to apply for property assessment, registration, insurance, notary etc. procedures, involving many departments, and to provide more relevant information, for the habit of flexible management of small and medium-sized enterprises in terms of will undoubtedly bring greatly restricted. And mortgage registration and assessment of high cost, free of charge, the bank loan mortgage rate for enterprises is low, the actual amount of the loan business through the mortgage is relatively small.

\section{Solving the financing difficulties of small and medium sized enterprises}

The government should strengthen the macro-control functions, focus on the development or improvement of preferential policies for small and medium enterprises financing. The small and medium-sized enterprise management scale is small, resists the market risk and the fund management ability difference and so on characteristic has decided it through the market financing credit very low characteristic. This objectively requires the state to give appropriate support through a stable financing mechanism. We can draw lessons from Japan, the United States and other countries successful experience, according to the situation of our country to develop the current situation of small and medium-sized enterprises in the development of laws, regulations and preferential policies.

Establishing of small and medium enterprises fund. Fund for small and medium enterprises, including specific uses of funds, guarantee funds, venture capital funds, mutual funds and the source of funds can be at all levels of government financial institutions and small and medium-sized enterprise entrance fee, management of the implementation of fund closed operation, focused on supporting the development of small and medium-sized enterprises.

Speeding up the establishment of credit guarantee system for small and medium enterprises. SME credit guarantee institutions to serve as the purpose of the intermediary organizations, can not be the main purpose of profitability, security fees charged, not to increase the cost of financing for small and medium enterprises as the cost. The State Economic and Trade Commission, State Administration for Industry and commerce, the Ministry of Finance and other 10 ministries jointly made the on strengthening credit management of small and medium enterprises in a number of opinions "guide SMEs to enhance the sense of credit, improve the credit status, to create a good credit environment, to provide various forms of service for the financing of small and medium-sized enterprises, to accelerate the pace of the construction of China's social credit system, which marks China to small and medium-sized enterprises as the main body of the social credit system construction started. At the same time, small and medium-sized enterprises should actively participate in credit insurance and credit guarantee to change their financing environment.

Small and medium enterprises should strengthen their own financial management. Small and medium-sized enterprises to form a reasonable capital structure, to determine a reasonable proportion of liabilities, improve the ability to withstand financial risks, but also pay attention to the long-term development of enterprises can not be restricted. Accelerate the accumulation of funds, as much as possible to improve the depreciation rate, reduce administrative expenses and other non productive expenses, etc., in order to change the credit credit capacity of enterprises. To effectively 
use the existing idle capital and inventory, through the mortgage, financing, lease financing, mortgage corporate bonds and other financing channels for corporate financing.

\section{Conclusion}

The financing of small and medium-sized enterprises is a process of transformation from endogenous to exogenous and the best combination of economic development. Through the above analysis, the author thinks that to improve the financing environment for small and medium-sized enterprises, and effectively solve the financing difficulties of enterprises is a problem to be solved. Such as through policy guidance and build a platform to make the role of the main channel of bank financing of small and medium-sized enterprises increased, the formation of a new situation of "big bank service of small and medium enterprises"; in the industrial enterprise financing as the key the project system project to build financing needs, joint financing service agencies to implement project financing support, and from the project in the selection of a group of both the financing demand and development potential of the enterprise as the most valuable enterprise financing, give credit, financing, policy support and intellectual support package to foster and support, to improve the executives the financing capacity of a number of enterprises; encourage and support enterprises through the trust collection of notes, a collection of bonds, risk investment, direct Financing, optimizing the financing structure of enterprises to actively carry out financial leasing business, to meet the needs of enterprises to purchase equipment and fixed assets, to solve the problem caused by the lack of collateral financing difficulties.

\section{Reference}

[1] Lei Liyuan, Chen Hong. Research on financing difficulties and Countermeasures of high and new technology enterprises [J]. time finance. 2016 (18)110-119.

[2] Zhao Bin. Small and micro enterprises financing plight crack path [J]. accounting communication. 2016 (20) 201-211.

[3] Tong Xiao. Financing difficulties and Countermeasures of small and micro enterprises [J]. modern trade and industry. 2016 (09) 90-91.

[4] Wu Qian. Analysis of the current situation of the financing difficulties of small and medium-sized enterprises in China -- a case study of Langfang city [J]. 2015 (29) 112-119. 